\title{
Legal Protection of The Rights of The Child Conflict with The Law in Criminal System in Indonesia
}

\section{Titin Prialianti ${ }^{1}$}

\begin{abstract}
Kids are the future generation, since the past becomes a fact not in dispute. However, children and life does not always experience the world like a child's journey. Child and his life is a hope and a future generation that will bring Indonesia into a more dignified nation, because from an early age the child is equipped with moral education, religious, and cultural attitudes Indonesia known friendly and have a high tolerance. But in reality the child's life is not always straight and provide the ultimate comfort of the child's world. The fact is not little children who should have cute and adorable behavior actually stuck on adult human life is not worth living children. Children who entered into a legal conflict issues requires more attention to find a way out, a solution and not reckless handling so as not to negatively impact children. Revision to Act No. 3 of 1997 on Juvenile Justice into Act No. 11 of 2012, concerning child Criminal Court System, provides a decent enough room for children coming into conflict of laws. Quite feasible because in the Act No. 11 of 2012 which contains 108 Article, more humane in the treatment of children coming into conflict of laws.

Keywords: Legal Protection; Rights of the Child in conflict.
\end{abstract}

\section{Introduction}

Kids as young generation is the nation's assets. As the nation's assets child is the successor to the struggle and ideals of the nation and human resources for national development. The position of the child as a national asset of course must also be balanced with protection in the order of his life, well since he was still in the womb or at birth, then grow and develop. The child should have a comfortable life, safe and grow in a healthy child's world. Healthy in the sense of the word of sound body and healthy soul.

In fact youth development efforts, are often faced with various problems that are difficult to avoid. Among others, the emergence of deviant behavior of children who act out of character as a child. Even further than that not a few children who have violated the law, whether they are derived from the weak economy, middle or upper though.

Other conditions that created the appearance of a group of abandoned children, the children who for various boss unmet need with a reasonable, well need spiritual, physical, social and economic. From this group there are also a variety of problems, with diverse reasons. Whether it is to preserve life, fulfilling life or because of the behavior of the community. The grounds also varies often children from these groups often perform actions that harm others, whether it was intentional, unintentional or forced by circumstances as a result of her social community.

However because children who grow flowers in the community individually or in groups tend to behave worse still had a negative impact on children who are growing flowers. However the environment is a factor that most potential and has a strong influence on the children around him.

Even in science of crimonology tendency of children with a criminal offense is probably

\footnotetext{
${ }^{1}$ Student of Master of Law, Universitas Islam Sultan Agung Semarang and A reporters of Cirebon email: prialianti@gmail.com
} 
influenced by the environment and a place to socialize. Although since the beginning of the parents and the family is equip with good moral education, in case of meeting time constraints and unfavorable environmental influences. Then the child may have deviations in behavior and in the end had to face conflict with the law, it may happen.

Child's actions that led to the unlawful behavior or acts forbidden for children, not only led to concerns, while making all parties must participate in discussion to cope. Neither of the establishment of a harmonious environment in the family, social order is maintained in quality, as well as strong protection to avoid the entry of foreign influence and technology, the negative-leaning.

Of these factors, the family or the relationship between parents and children is an essential relationship, both psycology and mentally spiritual. Given the nature of these relationships in human life, it is in the handling of cases of children, the role of the family to be very special to the solution are not adversely affected the physical and spiritual development. Do not destroy the future of children and do not cause traumatic due to bad acts ever face $^{2}$

Efforts notice aberrant behavior carried the child and to protect children from an unhealthy development when children are forced to deal with justice, is already proven to be a concern of all parties. Among others, held a scientific meeting both the government and the elements that concern about the child. Organized seminars which resulted in the formulation of how to provide protection against teenagers and shelter.

The various scientific meetings, as well as input also concluded the need for the protection of children litigants with the law. Furthermore, children who are forced to deal can be done in the public courts. With the enactment of Act No. 3 of 1997 on Juvenile Justice was later revised to Act No.11 of 2012 on Child Criminal Court System, provides an opportunity for children to still be able to grow a reasonable healthy growth.

This firmness is listed in several changes on the article of the Act No. 3 of 1997 by Act No. 11 of 2012. The change in the number of clauses and provisions on the handling of juvenile justice gives more space to appreciate and rescuing children from the trauma children face post handling the case.

From the above is taken the problem is how the protection of the rights of children in conflict with the law in the juvenile criminal system in Indonesia?

\section{Results And Discussion}

The case of children in conflict with the law can be the author happens to DD. Eleven-yearold boy sentenced to two months in prison in Siantar, North Sumatra, for stealing laptops and cell phones. When he was released due to finish serving prison time on Thursday, June 6,2013 , he did not know where to return where. Parents and family reject the presence of DD due to embarrassment.

Even during at the level of investigation until breaking verdicts and DD serving a sentence of two months in prison, none of his family who visit her. For an eleven year old child committed the theft with a reason to buy toys, apparently still considered reasonable notice the age limit was 12 years old that have not (yet considered mature psychologically). Moreover, with the enactment of Act No. 11 Of 2012 on Child Criminal Court System, which clearly mentions children under the age of 12 years, unenforceable received a prison

\footnotetext{
${ }^{2}$ M. Nasir Djamil 2013 Anak Bukan untuk Dihukum Sinar Grafika Jakarta p.54
} 
sentence.

On the other hand, parents DD as lecturer at leading universities in Siantar, are themselves dump him because of shame found the child had stolen. In fact, when looking at the background of parents DD are an educator, it's hard to accept when the family environment is not able to protect the life of a child. So how about the next life for DD, when his own parents give a more severe punishment than a prison sentence of two months ever received. DD really do not know where to return where time out of Siantar prison. He no longer had a place to stay that is covered by the love of his parents.

DD melancholy story, do sharp sense of wonder, who should responsible when children make conflict with the law? Do DD itself is already stealing laptops and cell phones? Does the responsibility of parents are "not good" when parents educate a lecturer DD "? Are the law enforcement since the beginning involved in the investigation, investigation, until the hearing child?

Though written in the Act No. 11 Of 2012, Article 55 paragraph (1); in hearing the child, the judge should instruct the parent / guardian or lawyer or other legal aid providers and community counselors to accompany the child. In the next article mentioned if these parties do not come then the judge can cancel the trial.

To see what happens in the DD should children do not deserve such treatment, because there are some changes that are considered to save the child from trauma psycology and its future included:

- In Article 1 of Act No. 3 of 1997 mentioned a child is a person who in the case of naughty children have reached the age of 8 (eight) years. Predicate brat, certainly not a good term to be strapped to the child. Mentions brat still give a bad connotation especially in conditions faced to court.

Mentions brat is no longer used in the Act No. 11 of 2012. Stated in Article 1 Paragraph 2 of Act No. 11 of 2012, children in conflict with the law are children in conflict with the law. Designation eliminates brat in Act No. 11 of 2012, not only provides an opportunity for children who have been litigating with the law to be aligned with other children, because they do not have a special designation as a brat. Is the extraordinary form of protection is done for the children should have a good future and not be embarrassed by it bears status as a brat.

- Age limit of children who may be exposed in the trial stated in Act No. 3 of 1997 is 8 years old, assertiveness was stated in Article 4 Paragraph 1 which reads, the age limits brat that can be submitted to the Assembly Son is at least 8 (eight) years, but has not reached the age of 18 years. The sound of that article, however, not represent the interests of children from side psycology. Child age limit can be raised in the age of 8 years is considered too young and children 8 years rated not yet have the maturity in psycology by the standards of Indonesian children.

- Changes in child age limit that can be faced in court carried a child in Act No. 11 Of 2012, listed in Article 1 Paragraph 3, which says, children in conflict with the law, hereinafter referred to child is a child who is aged 12 years. Changes in the age limit is confirmed by the decision of the Constitutional Court in a hearing at the Court House on Thursday, 24 February 2012, with the decision that the age limit of children who can be held criminal liability is a child who was aged 12 years. Because children age 12 is considered to have had emotional intelligence, have sufficient intellectual and 
development of the child in accordance with standard child psycology in Indonesia.

- Placing children litigants to keep having activity as other children who have the same rights to get future and ideals, is expressly stated in the Act No. 11 Of 2012, Article 73 Paragraph 8, which affirmed, during his conditional punishment, the child must attend nine-year compulsory education. The firmness of the obligation of children to continue to receive education in childhood undergo conditional sentence, was not included in the Act No. 31997 chapter 29 verse 1 to 9, which also confirmed the possibility of children getting a criminal on parole.

Assertiveness in Act No. 11 of 2012, concerning the obligation of children to follow the nine-year compulsory education, is the government's responsibility to keep attention to children as young people and have the same opportunity to build a nation of Indonesia as a dignified nation. This opportunity provides the broadest opportunity for children to pursue an education without having to look at the background.

- The most striking change, and position the child as a baby who should be protected actually looks in Act No.11 of 2012 article 71 which confirms the sentence imposed on the child. Article (1) expressly stated, the principal criminal in children consists of: (1) crime warning, (b) criminal on the condition, (2) Development of outside agencies, (3) Public services, C Job Training, d. Coaching in the institution, e. Jail.

Compare with the content of Act No. 3, 1997 Article 23, Paragraph (2), which reads: principal criminal to impose such a brat is: a) imprisonment (b) imprisonment, (c) criminal fines (d) criminal supervision ${ }^{3}$

How the fate of the children with the law for the criminal justice agencies, prison precisely placed in the most important position as stated in Act No. 3 of 1997? Is not there a word of apology to children in conflict with the law or the lives of children must be ended only up to here?

What will happen to the development of his soul when confinement prison becomes considered able to make the child a deterrent. Meanwhile, although there are efforts to separate children who shall be punished with adult criminal chamber, does not mean that the two do not interact, because it has not fulfilled that specializes criminal adequate means for children.

The most important thing in Act No.11 of 2012, confirms all the components involved in handling in the juvenile justice is more approach to the safety of children during children experience the process and conflict with the law. As firmness listed in Article 2:

The Criminal Justice System implemented based on the principles of: (a) protection, (b) equity, (c) non-discrimination, (d) the best interests of the child, (e) respect for the views of the child, (f) the survival and development of the child, (g ) coaching and mentoring children, (h) proportional, (i) the deprivation of liberty and judgement as a last resort, (j) avoidance of retaliation.

Listening and review more about the criminal justice system in children and how components supporters react with the mission, vision and the same view, wanted to save her from destruction worse because there is a device that is one of enacting and treat children in conflict with the law.

Listening and examine the importance of children getting treatment and special attention

\footnotetext{
${ }^{3}$ Angger Sigit Pramukti SH \& Fuady Primaharsa SH 2005 Sistem Peradilan Pidana Anak Pustaka Yustisia p.39
} 
to children in conflict with the law, the scope of the problem in this research is specifically defined and limited as follows:

- The enactment of Act No. 11 Of 2012 on Child Criminal Court System, have to accommodate the interests of children and save the child completely from the trauma and impact psycology.

- All the components and justice agencies involved in the juvenile justice must be able to meet the requirements stipulated in Act No.11 of 2012.

- Facilities and infrastructure needed to Act No. 11 of 2012 must be met so that it can be applied since at the level of investigation to the detention center when children are dealing with a criminal offense.

- Required readiness and empathy for the child's future from the legal apparatus for the possible emergence of legal action for himself when in the juvenile justice process turned out not to comply and provide protection in accordance with Act No. 11 of 2012, because it may be the enforcement this law may be subject to criminal penalties if either enforce the child during the judicial process.

- Society and the mass media must respond either a problem with children in conflict with the law related to news that affects the child psycology.

\section{Closing}

\subsection{Conclusion}

The result is Act 4 of 1979 About Welfare of the Child. In connection with the various inputs on juvenile justice for children who are misbehaving and breaking the law, with fears the emergence of arbitrariness in treating children when children are dealing with the law, then in 1979 the Ministry of Justice initiated the drafting of laws Juvenile Justice until the enactment of Act No. 3 of 1997 on Juvenile Justice

In addition to the legislation that specifically touch on efforts to protect the children. Some of the legislation that already exists also emphasizes the need for protection of children include:

- Civil law. Provisions in civil law include the following: the position of a legitimate child and legal heir; recognition and validation of a child outside of marriage; obligations of parents towards children; under age children and guardianship

- Criminal law. In addition under Article 45, 46 and 47 of the Criminal Code are also several chapters that are directly or indirectly related to the protection of children, among other things Articles 278, 283, 287, Article 290, Article 297, Article 301, Article 305, Article 308, Article 341, Article 356 of the Criminal Code

- Employment law. Regulated in Act No. 13 of 2003, Article 68 with the provisions, employers are prohibited from employing children.

While specific regulation that directly adopt children as subjects to be covered include: RI Constitution of 1945, Article 5 Paragraph (1), Article 20 Paragraph (1); Act No. 12 of 1995 regarding Correctional Children; Act No. 11 of 2012. Other considerations Act No. 3 of 1997 on Juvenile Justice, is no longer relevant to the development and needs of the community law, because it has yet to be comprehensible provides protection to children in conflict with the law ${ }^{4}$; Jounalistic Code (KEJ) Association of Indonesian

\footnotetext{
${ }^{4}$ Dr. Romli Atmasasmita SH LLM Peradilan Anak di Indonesia Mandar Maju,.
} 
journalists.

In the Journalistic Code of Ethics (KEJ) PWI Article 5 explicitly contain, Indonesian journalist does not mention the identity of crime victims and broadcast decency and not to mention the identity of children who become criminals.

This firmness provide interpretation explicitly, the so-called identity is all the data related to someone who allows others to track his whereabouts. While the age limit of children in the Code of Ethics of Journalism, is a 16-year-old who has not yet married.

That is news to bring any small child as a person in conflict with the law (the so-called perpetrators of the crime KEJ), the mass media should not mention the identity of the children are usually camouflaged with the name Flowers, Jasmine or Rose. Not being allowed to call identity either as victims or perpetrators, a refuge for children in conflict with the law for children in conflict with the law should not lose their future ${ }^{5}$

\subsection{Suggestion}

- To examine more in the application of Act No. 11 of 2012 so that the judicial process faced by children in conflict with the law does not make the child's psyche shaken, not break the development of the child, and did not make children lose their rights as a child the expectations of Indonesian people.

- Expected to assess the constraints faced since the child entered in the conflict of law until a court decision the decline of the "fate" of children who enter the juvenile criminal trial process.

- It is expected to give a sense of greater empathy to law enforcement and elements that are not directly or indirectly involved in the process of hearing the child, so that a sense of empathy raises the spirit to jointly save the future of the child and not just performing their duties as law enforcers.

- Expected to raise awareness for the entire community to equally protect and safeguard the children so that future generations are not stuck in a legal conflict that led to the loss of hope of a generation.

\section{References}

[1] HS.Cl. Harsono 1995 Sistem Baru Pembinaan Nara Pidana Djambatan: Jakarta.

[2] Moeyanto SH 2009 Asas Teori Praktek Hukum Pidana Bina Aksara: Jakarta.

[3] Muhammad Ibnu Abdul Hafidh Suwaid Ir Cara Nabi Mendidik Anak Al-I tishom Cahaya Umat.

[4] Act of 1945: Constitution of the Republic of Indonesia Already Amended and explanation 2014 Serbajaya Surabaya.

[5] Act No. 11 Of 2012 on Children Criminal Court Systern 2012. Sinar Grafis: Jakarta.

[6] Nashriana 2011 Act No. 3 of 1997 on Juvenile Justice University of Diponegoro Semarang

[7] Act No. 12 Year 1995 regarding Correctional Children

[8] Act No. 13 Of 2003 on Manpower 2010 Citra Umbara: Jakarta.

[9] Journalist Code (KEJ) Indonesian Reporter Association

\footnotetext{
${ }^{5}$ Drs. AS Haris Sumadiria M.Si Hukum Etika Media Massa 2016 Simbiosa Rekatama Media
} 